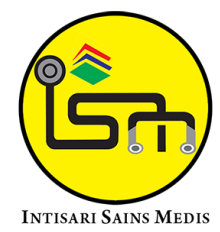

Published by Intisari Sains Medis

\section{Hubungan Lymph Vessel Density (LVD) dengan invasi limfatik dan metastasis kelenjar getah bening regional pada karsinoma payudara invasif tipe tidak spesifik di RSUP Sanglah, Bali, Indonesia}

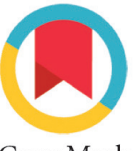

CrossMark

\author{
Katrin Rotua Simbolon ${ }^{1 *}$, I Gusti Ayu Sri Mahendra Dewi ${ }^{1}$, Ni Putu Sriwidyani', \\ Luh Putu lin Indrayani Maker', Herman Saputra ${ }^{1}$, I Made Muliarta ${ }^{2}$
}

\section{ABSTRACT}

Background: Lymph Node Metastasis (LNM) is considered the most important prognostic factor in breast cancer. The progress of lymphatic metastasis is thought to involve the proliferation of lymphatic vessels (lymphangiogenesis), Lymph Vessel Invasion (LVI), and lymph node metastasis step by step. This study aims to evaluate the association between LVD with LVI and regional LNM in invasive breast carcinoma of no special type.

Methods: This study used a cross-sectional analytical study, using a sample of 38 paraffin-embedded tissue from the patient with invasive breast carcinoma of no special type in Sanglah General Hospital, Bali, Indonesia, in 2018. The sample will be used to assess LVD and LVI by D2-40 immunohistochemistry. Expression of D2-40 with vigorous-intensity was evaluated on the membrane and cytoplasm of lymphatic endothelial cells to determine the definition of lymphatic vessels. Lymph vessel density was determined by counting the

Keywords: Lymph Vessel Density, Lymph Vessel Invasion, D2-40, Invasive Breast Carcinoma.

Cite This Article: Simbolon, K.R., Dewi, I.G.A.S.M., Sriwidyani, N.P., Maker, L.P.I.I., Saputra, H., Muliarta, I.M. 2021. Hubungan Lymph Vessel Density (LVD) dengan invasi limfatik dan metastasis kelenjar getah bening regional pada karsinoma payudara invasif tipe tidak spesifik di RSUP Sanglah, Bali, Indonesia. Intisari Sains Medis 12(2): 606-612. DOI: 10.15562/ism.v12i2.1037

\section{ABSTRAK}

Kedokteran, Universitas Udayana, RSUP Sanglah, Bali, Indonesia;

${ }^{2}$ Departemen Fisiologi, Fakultas Kedokteran, Universitas Udayana, Bali, Indonesia;

\section{*Korespondensi:}

\section{Katrin Rotua Simbolon;}

Departemen Patologi Anatomi, Fakultas Kedokteran, Universitas Udayana, RSUP Sanglah, Bali, Indonesia; dr.katrinsimbolon@gmail.com number of lumens of peritumoral lymphatic vessels in five fields of view with the densest lymphatic vessel lumen using a Leica microscope (DM750, 400x, area $0.225 \mathrm{~mm} 2$ ). Data were analyzed using SPSS version 24 for Windows.

Results: The LVD cut-off value is 16.5 lymphatic vessel lumens $/ 0.225 \mathrm{~mm} 2(65.4 \%$ for sensitivity and area Under the Curve $(A \cup C)=70.2 \%)$. Then cases were classified into the category of high LVD ( $\geq 16,5$ lymphatic vessel lumen/0,225 $\mathrm{mm}^{2}$ ) and low LVD $\left(<16.5\right.$ lymphatic vessels lumen $/ 0,225 \mathrm{~mm}^{2}$ ). The study found a statistically significant association between LVD and lymph vessel invasion ( $P R=3.6 ; p=0.043$; $95 \%(\mathrm{Cl}=0.88-14.78)$ and regional lymph node metastases ( $P R=1.7 ; p=0.02 ; 95 \%(l=1.03-2.79)$.

Conclusion: This study proved an association between LVD with lymph vessel invasion and regional lymph node metastases.
Latar Belakang: Metastasis Kelenjar Getah Bening (KGB) dianggap sebagai faktor prognostik yang paling penting pada kanker payudara. Perkembangan metastasis limfatik diduga melibatkan proliferasi pembuluh limfatik (limfangiogenesis), Lymph Vessel Invasion (LVI) atau invasi limfatik, dan metastasis kelenjar getah bening secara bertahap. Penelitian ini bertujuan untuk mengevaluasi hubungan antara Lymph Vessel Density (LVD) dengan invasi limfatik dan metastasis kelenjar getah bening regional pada karsinoma payudara invasif tipe tidak spesifik.

Metode: Penelitian ini menggunakan metode analitik potong lintang dengan sampel 38 blok parafin dari pasien karsinoma payudara invasif tipe tidak spesifik di RSUP Sanglah, Bali, Indonesia tahun 2018. Penilaian LVD dan LVI dengan pulasan imunohistokimia D2-40. Ekspresi D2-40 dengan intensitas yang kuat dievaluasi pada membran dan sitoplasma sel endotel limfatik untuk menetapkan definisi pembuluh limfatik. Lymph vessel density ditentukan dengan menghitung jumlah lumen pembuluh limfatik peritumoral pada lima lapangan pandang yang memiliki lumen pembuluh limfatik terpadat, menggunakan mikroskop Leica (DM750, 400x, luas area 0,225 $\mathrm{mm}^{2}$ ). Data dianalisis 
dengan SPSS versi 24 untuk Windows.

Hasil: Nilai cut-off LVD adalah 16,5 lumen pembuluh limfatik/0,225 mm² (sensitivitas 65,4\% dan Area Under the Curve $(A \cup C)=70,2 \%)$. Kemudian kasus dikategorikan menjadi LVD tinggi ( $\geq 16,5$ lumen pembuluh limfatik / 0,225 $\mathrm{mm} 2$ ) dan LVD rendah $(<16,5$ lumen pembuluh limfatik / 0,225 mm2).
Hasil analisis statistik menunjukkan bahwa terdapat hubungan antara LVD dengan invasi limfatik ( $P R=3,6$; $p=0,043$; IK $95 \%=0,88-14,78)$ dan metastasis KGB regional ( $P R=1,7 ; p=0,02 ; \mathrm{IK} 95 \%=1,03-2,79)$.

Kesimpulan: Penelitian ini membuktikan bahwa terdapat hubungan antara LVD dengan invasi limfatik dan metastasis KGB regional.

Kata kunci: Lymph Vessel Density, Invasi Limfatik, D2-40, Karsinoma Payudara Invasif.

Sitasi Artikel ini: Simbolon, K.R., Dewi, I.G.A.S.M., Sriwidyani, N.P., Maker, L.P.I.I., Saputra, H., Muliarta, I.M. 2021. Hubungan Lymph Vessel Density (LVD) dengan invasi limfatik dan metastasis kelenjar getah bening regional pada karsinoma payudara invasif tipe tidak spesifik di RSUP Sanglah, Bali, Indonesia. Intisari Sains Medis 12(2): 606-612. DOI: 10.15562/ism.v12i2.1037

\section{PENDAHULUAN}

Kanker payudara merupakan kanker ganas yang sering terjadi pada wanita dan sering bermetastasis baik melalui sistem limfatik maupun hematogen. Metastasis pada kanker payudara sering menyebabkan kematian meskipun ada kemajuan dalam terapi dan penelitian. ${ }^{1-3}$ Pada karsinoma payudara, penyebaran preferensial melalui pembuluh limfatik berasal dari frekuensi invasi limfatik (Lymph Vessel Invasion atau LVI) lebih tinggi dibandingkan dengan invasi pembuluh darah (Blood Vessel Invasion atau BVI). ${ }^{1-3}$

Perkembangan metastasis limfatik diduga melibatkan proliferasi pembuluh limfatik (limfangiogenesis), invasi limfatik, dan metastasis kelenjar getah bening secara bertahap. Namun, kemungkinan hubungan lymph vessel density (LVD), invasi limfatik (Lymph Vessel Invasion atau LVI), dan metastasis kelenjar getah bening masih belum jelas. ${ }^{3,4}$ Mekanisme yang menyebabkan sel tumor menyebar melalui pembuluh limfatik atau LVI juga belum dapat dibuktikan dengan jelas. ${ }^{4}$ Protein yang menginduksi limfangiogenesis adalah reseptor faktor Vascular Endothelial Growth Factor-3 (VEGFR-3), yang diaktivasi oleh Vascular Endothelial Growth Factor-C dan D (VEGF-C dan VEGF-D). ${ }^{3,5}$ Faktor-faktor limfangiogenik ini biasanya diekspresikan dalam sel-sel ganas, tumor-infiltrating cell dan sel stromal, menciptakan lingkungan yang menguntungkan untuk pembentukan pembuluh limfatik baru. Pembuluh limfatik akan mengalami perubahan berupa peningkatan jumlah (limfangiogenesis) dan diameter pembuluh limfatik. Akibatnya, aliran getah bening meningkat sehingga meningkatkan aliran metastasis sel tumor menuju ke kelenjar getah bening dan dapat berkontribusi pada penyebaran sistemik. Namun, sel-sel tumor juga dapat menggunakan penarik fisiologis seperti Stromal Cell-Derived Factor-1 (SDF1) (juga dikenal sebagai $C-X-C$ Motif Chemokine Ligand 12 atau CXCL12) dan C-C Motif Chemokine Ligand 21 (CCL21) untuk bermigrasi melalui saluran limfatik menuju kelenjar getah bening regional. Peningkatan LVD secara signifikan meningkatkan potensi sel tumor untuk menginvasi permukaan pembuluh limfatik. ${ }^{3}$ Pembuluh limfatik baru dapat menyediakan jalur tambahan untuk transit sel tumor, sehingga memperkuat aktivitas pro-metastasis dari pembuluh limfatik yang sudah ada sebelumnya yang terletak peritumoral. ${ }^{3}$ Limfangiogenesis dapat ditentukan secara kuantitatif yaitu menghitung kepadatan pembuluh limfatik (LVD) dengan menggunakan penanda sel endotel limfatik yang spesifik seperti podoplanin/D2-40. ${ }^{3}$

Status kelenjar getah bening digunakan untuk mengidentifikasi prognosis pasien, stadium tumor dan modalitas terapi. ${ }^{1,6}$ Metastasis kelenjar getah bening dianggap sebagai faktor prognostik yang paling penting pada kanker payudara. ${ }^{7}$

Beberapa penelitian menunjukkan hasil bahwa LVD berhubungan dengan LVI dan metastasis kelenjar getah bening., ${ }^{4,8}$ Penelitian Kanngurn $S$ et al., [10] menunjukkan bahwa tidak terdapat hubungan signifikan antara LVD dengan metastasis kelenjar getah bening regional pada karsinoma payudara.

Antibodi monoklonal D2-40 berguna dan dapat diandalkan untuk mendeteksi invasi limfatik, hingga 2 kali lipat bila dibandingkan dengan pulasan $\mathrm{H}$ dan $\mathrm{E}$ saja. ${ }^{4,10-12}$ Antibodi monoklonal D2-40 merupakan penanda sel endotel limfatik dengan sensitifitas dan spesifitas tinggi yang terpulas kuat pada sel endotel limfatik tetapi tidak pada sel endotel pembuluh darah. ${ }^{11}$

Berdasarkan pada pemaparan di atas, maka penelitian ini bertujuan untuk mengetahui hubungan antara LVD dengan LVI terhadap metastasis KGB regional pada karsinoma payudara invasif tipe tidak spesifik di Bali.

\section{METODE}

Penelitian ini merupakan penelitian observasional menggunakan rancangan studi analitik potong lintang untuk mengetahui hubungan antara LVD dengan invasi limfatik dan metastasis kelenjar getah bening regional pada karsinoma payudara invasif tipe tidak spesifik dengan menggunakan imunohistokimia D2-40 sebagai penanda sel endotel limfatik di RSUP Sanglah Denpasar.

Sampel penelitian adalah penderita karsinoma payudara invasif tipe tidak spesifik yang dilakukan operasi Modified Radical Mastectomy (MRM) dan sediaan blok parafinnya diperiksakan di Laboratorium Patologi Anatomi RSUP Sanglah Denpasar dari tanggal 1 Januari sampai 31 Desember 2018 yang memenuhi kriteria inklusi dan eksklusi 
yang ditetapkan oleh peneliti. Kriteria inklusi yang dipakai yaitu blok parafin dari pasien karsinoma payudara invasif tipe tidak spesifik yang dilakukan MRM dan belum mendapat kemoterapi dan atau radioterapi sebelum tindakan MRM. Bila sudah mendapat kemoterapi dan atau radioterapi sebelum MRM, maka dicari blok parafin dari sediaan open biopsy. Blok parafin dalam kondisi baik dan masih mengandung jaringan yang cukup untuk dilakukan pemotongan ulang serta data klinikopatologi yang lengkap meliputi umur, ukuran tumor, status nodal, derajat histologik (grade), invasi limfovaskular (HE) dan metastasis KGB regional tercantum pada Sistem Informasi Manajemen Rumah Sakit (SIMARS) RSUP Sanglah atau formulir histopatologi atau data rekam medis. Kriteria eksklusi yang dipakai yaitu data klinikopatologi yang tidak lengkap setelah dilakukan penelusuran melalui sistem SIMARS atau formulir histopatologi atau data rekam medis. Jumlah kasus yang memenuhi kriteria inklusi dan eksklusi sebanyak 38 kasus.

Lymph vessel density adalah jumlah lumen pembuluh limfatik yang dipindai dengan mikroskop cahaya binokuler Leica DM750, menggunakan perbesaran rendah (40X). Kemudian dinilai pada area peritumoral dengan jumlah microvessel terpadat yang terpulas positif kuat terhadap D2-40 pada membran dan sitoplasma sel endotel [3]. Selanjutnya jumlah lumen pembuluh limfatik dihitung pada lima hotspot yang dipilih, menggunakan mikroskop Leica DM750, perbesaran 400X (luas area $0,225 \mathrm{~mm}^{2}$ ). Nilai batas cut-off ditentukan dengan menggunakan arah kurva Receiver Operating Characteristic (ROC) dimana metastasis KGB regional digunakan sebagai outcome. Nilai cut-off tersebut digunakan untuk mengkategorikan LVD menjadi tinggi dan rendah. Interpretasi ekspresi D2-40 dalam menentukan jumlah lumen pembuluh limfatik dilakukan oleh peneliti dan 2 orang dokter spesialis patologi anatomi, tanpa mengetahui data klinikopatologi pasien. Bila terjadi perbedaan pendapat tentang interpretasi ekspresi D2-40 dilakukan kesepakatan bersama secara konsensus.

Invasi limfatik adalah adanya emboli
Tabel 1. Karakteristik responden penelitian

\begin{tabular}{lcc}
\hline \multicolumn{1}{c}{ Karakteristik } & Frekuensi (n) & Persentase (\%) \\
\hline Usia & 5 & 13,2 \\
$<40$ tahun & 33 & 86,8 \\
$\geq 40$ tahun & & \\
Ukuran tumor & 7 & 18,4 \\
T1 & 19 & 50,0 \\
T2 & 10 & 26,3 \\
T3 & 2 & 5,3 \\
T4 & & \\
Status nodal & 12 & 31,6 \\
N0 & 14 & 36,8 \\
N1 & 10 & 26,3 \\
N2 & 2 & 5,3 \\
N3 & & \\
Derajat histologik (grade) & 2 & 5,3 \\
1 & 15 & 39,5 \\
2 & 21 & 55,3 \\
3 & & \\
Invasi limfovaskular (HE) & 21 & 55,3 \\
Positif & 17 & 44,7 \\
Negatif & & 68,4 \\
Metastasis KGB regional & 26 & 31,6 \\
Positif & 12 & \\
Negatif & &
\end{tabular}
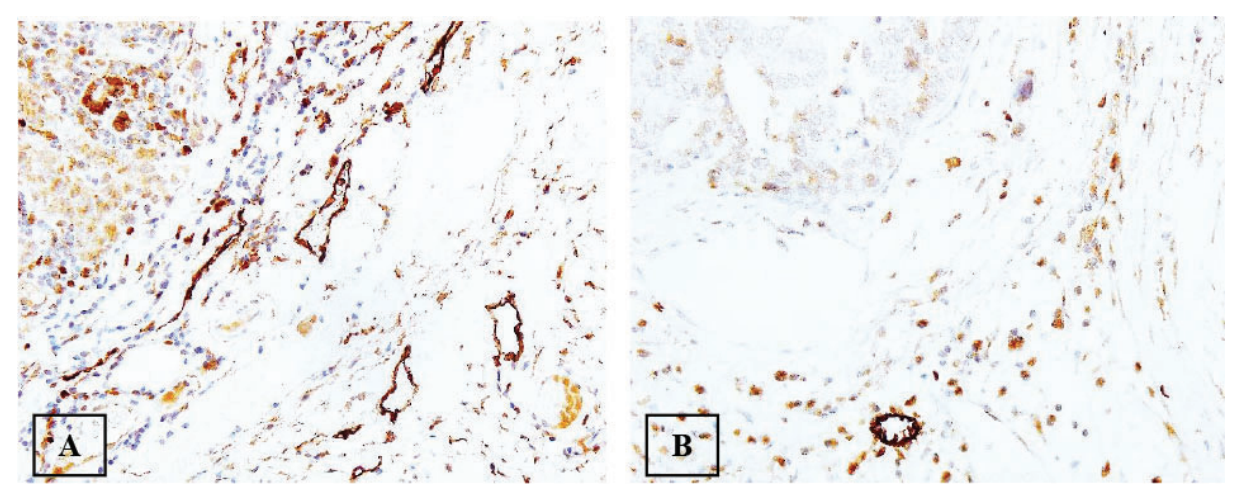

Gambar 1. Lumen pembuluh limfatik pada area peritumoral dengan pulasan imunohistokimia D2-40. (A) Lymph Vessel Density (LVD) yang tinggi (pembesaran 400X) dan (B) Lymph Vessel Density (LVD) yang rendah (pembesaran 400X).
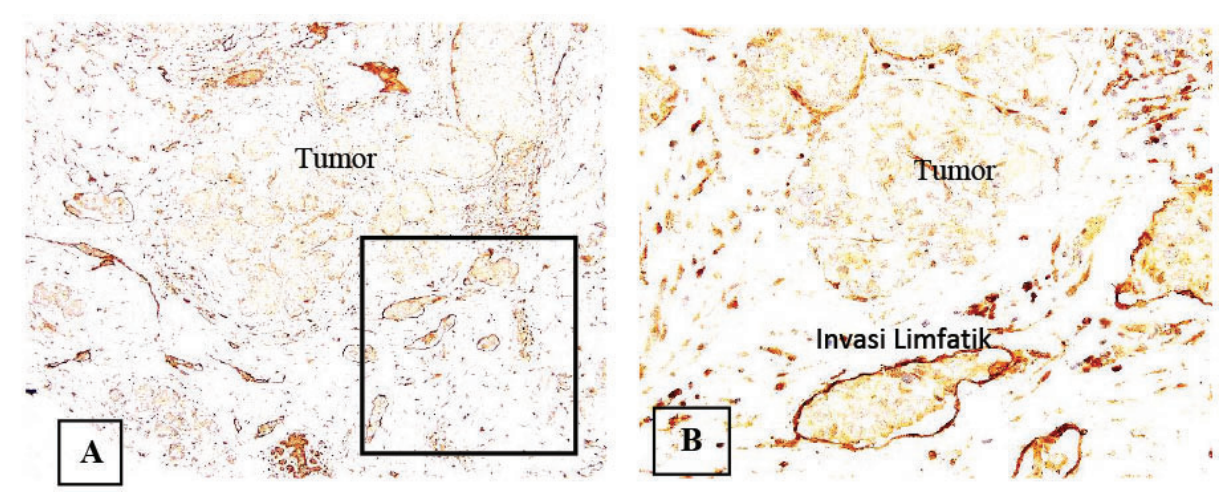

Gambar 2. (A) Invasi limfatik pada area peritumoral (D2-40, pembesaran 40X) dan (B) Invasi limfatik (D2-40, pembesaran 400X). 
Tabel 2. Hubungan LVD dengan invasi limfatik

\begin{tabular}{cccccc}
\multirow{2}{*}{ Variabel } & \multicolumn{2}{c}{ Invasi limfatik (N=38) } & \multirow{2}{*}{ PR } & 95\% IK & P \\
\cline { 2 - 3 } & Positif (N=10) & Negatif (N=28) & & & \\
\hline LVD, $n(\%)$ & & & 3,6 & $0,88-14,78$ & $0,043^{*}$ \\
Tinggi & $8(40,0 \%)$ & $12(60,0 \%)$ & & & \\
Rendah & $2(11,1 \%)$ & $16(88,9 \%)$ & &
\end{tabular}

PR: Prevalence Ratio; IK: Interval Kepercayaan; ${ }^{\star}$ Chi-Square: secara statistik bermakna apabila nilai $\mathrm{p}$ kurang dari 0,05 .

Tabel 3. Hubungan LVD dengan metastasis KGB regional

\begin{tabular}{cccccc}
\hline \multirow{2}{*}{ Variabel } & \multicolumn{2}{c}{ Metastasis KGB Regional (N=38) } & PR & 95\% IK & p \\
\cline { 2 - 3 } & Positif (N=26) & Negatif (N=12) & & & \\
\hline LVD, $n(\%)$ & & & & \\
Tinggi & $17(85,0 \%)$ & $3(15,0 \%)$ & 1,7 & $1,03-2,79$ & $0,02^{*}$ \\
Rendah & $9(50,0 \%)$ & $9(50,0 \%)$ & & & \\
\hline
\end{tabular}

PR: Prevalence Ratio; IK: Interval Kepercayaan; KGB: Kelenjar Getah Bening; ${ }^{\star}$ Chi-Square: secara statistik bermakna apabila nilai p kurang dari 0,05 .

tumor intravaskular yang melekat pada dinding pembuluh yang dilapisi endotel atau mengandung trombus dan atau fibrin di dalam pembuluh limfatik, dimana pembuluh limfatik ditandai dengan pulasan imunohistokimia D240. ${ }^{3}$ Positif : jika terdapat emboli sel tumor di dalam lumen pembuluh yang dilapisi oleh sel endotel dengan membran dan sitoplasma sel yang terpulas kuat terhadap Mouse Anti-Podoplanin [D2-40] (MC0329RTU7, Medaysis). Negatif : jika tidak terdapat emboli sel tumor di dalam lumen pembuluh yang dilapisi oleh sel endotel dengan membran dan sitoplasma yang terpulas kuat terhadap Mouse AntiPodoplanin [D2-40] (MC0329RTU7, Medaysis) atau membran dan sitoplasma sel pelapis terpulas lemah sampai sedang. Interpretasi ekspresi D2-40 pada sel endotel limfatik dilakukan pada area peritumoral (area yang terletak dalam jarak maksimal $2 \mathrm{~mm}$ dari tepi tumor yang invasif), secara blind dan independen tanpa mengetahui data klinikopatologi pasien.

Metastasis kelenjar getah bening dievaluasi secara histopatologi dengan menggunakan pulasan $\mathrm{H}$ dan E. Positif jika terdapat sel tumor di dalam KGB regional (mikrometastasis dan makrometastasis). Negatif jika tidak terdapat sel karsinoma dan atau terdapat sel tumor tunggal atau kelompok kecil sel yang luasnya tidak lebih dari $0,2 \mathrm{~mm}$ (isolated tumour cell cluster).

Data diolah dengan menggunakan
Program Statistical Package for the Social Sciences (SPSS) versi 24 untuk Windows. Analisis deskriptif meliputi karakteristik sampel. Analisis kurva ROC untuk menentukkan nilai titik potong (cut-off) LVD dan mengkategorikan LVD menjadi kategori tinggi dan rendah. Berdasarkan analisis kurva ROC LVD, didapatkan nilai cut-off LVD untuk memprediksi kejadian metastasis adalah 16,5 lumen pembuluh limfatik/0,225 $\mathrm{mm}^{2}$ dengan nilai sensitivitas $65,4 \%$ dan spesifisitas $75,0 \%$. Area Under the Curve (AUC) sebesar $70,2 \%$. Kemudian, nilai cut-off 16,5 lumen pembuluh limfatik/0,225 $\mathrm{mm}^{2}$ digunakan untuk membagi LVD menjadi kategori tinggi dan rendah. Dimana nilai cut-off $\geq 16,5$ lumen pembuluh limfatik/0,225 $\mathrm{mm}^{2}$ dimasukkan menjadi kategori LVD tinggi dan $<16,5$ lumen pembuluh limfatik/0,225 $\mathrm{mm}^{2}$ menjadi kategori LVD rendah. Uji Chi-square untuk menentukan hubungan antara LVD dengan invasi limfatik dan metastasis kelenjar getah bening regional.

\section{HASIL}

Berdasarkan karakteristik usia, didapatkan sebagian besar kasus memiliki usia $\geq 40$ tahun sebanyak 33 kasus $(86,8 \%)$ dan 5 kasus $(13,2 \%)$ memiliki usia $<40$ tahun, dengan rerata usia 50,53 tahun (rentang usia 30-67 tahun) dan median 51 tahun. Didapatkan sebagian besar kasus (81,6\%) memiliki ukuran tumor $>2 \mathrm{~cm}$ dan hanya sebagian kecil $(18,4 \%)$ kasus yang memiliki ukuran tumor $<2 \mathrm{~cm}$ (Tabel 1 ).
Sebagian besar kasus $(68,4 \%)$ didapatkan memiliki status nodal yang positif, status nodal N1 adalah yang terbanyak (36,8\%). Didapatkan lebih dari separuh kasus memiliki derajat histologi grade $3(55,3 \%)$, invasi limfovaskular (HE) (55,3\%) dan metastasis KGB regional (68,4\%). Data karakteristik klinikopatologi sampel dapat dilihat pada Tabel 1.

Pada penelitian ini didapatkan nilai rerata (mean) LVD sebesar 15,61 $\pm 7,24$, dengan LVD terendah 2 lumen pembuluh limfatik/0,225 $\mathrm{mm}^{2}$ dan yang tertinggi 28 lumen pembuluh limfatik/0,225 $\mathrm{mm}^{2}$. Hasil pulasan imunohistokimia D2-40 pada pembuluh limfatik yang menunjukkan lymph vessel density yang tinggi dan rendah dapat dilihat pada Gambar 1.

Pulasan D2-40 yang menunjukkan invasi limfatik dapat dilihat pada Gambar 2. Membran dan sitoplasma sel endotel pembuluh limfatik terpulas dengan intensitas yang kuat, mengandung emboli sel tumor di dalam lumennya. Pada penelitian ini, invasi limfatik yang positif dengan imunohistokimia D2-40 dan dievaluasi pada area peritumoral ditemukan sebanyak 10 kasus $(26,3 \%)$ (Gambar 2).

Pada 20 kasus dengan LVD tinggi, terdapat 8 kasus $(40,0 \%)$ dengan invasi limfatik positif dan 12 kasus $(60,0 \%)$ dengan invasi limfatik negatif. Pada 18 kasus dengan LVD rendah, terdapat 2 kasus $(11,1 \%)$ dengan invasi limfatik positif dan 16 kasus $(88,9 \%)$ dengan invasi limfatik negatif. Nilai rasio prevalensi sebesar 3,6 dan nilai $p=0,043$. Sehingga dapat disimpulkan bahwa terdapat hubungan antara LVD dengan invasi limfatik, dimana LVD yang tinggi akan memiliki peluang 3,6 kali lebih tinggi terhadap terjadinya invasi limfatik dibandingkan dengan kasus yang memiliki LVD rendah (Tabel 2).

Pada 20 kasus dengan LVD tinggi, terdapat 17 kasus $(85,0 \%)$ dengan metastasis KGB regional positif dan 3 kasus $(15,0 \%)$ dengan metastasis KGB regional negatif. Pada 18 kasus dengan LVD rendah, terdapat 9 kasus $(50,0 \%)$ dengan metastasis KGB regional positif dan 9 kasus (50,0\%) dengan metastasis KGB regional negatif. Nilai rasio prevalensi 1,7 dan nilai $\mathrm{p}=0,02$. Sehingga 
dapat disimpulkan bahwa terdapat hubungan antara LVD dengan metastasis KGB regional, dimana LVD yang tinggi akan memiliki peluang 1,7 kali lebih tinggi terhadap terjadinya metastasis KGB regional dibandingkan dengan kasus yang memiliki LVD rendah (Tabel 3).

\section{PEMBAHASAN}

Kanker payudara merupakan kanker tersering pada wanita dengan insiden $58.256(30,9 \%)$ dan merupakan penyebab kematian tersering ke 2 setelah kanker paru. $^{13}$ Sebagian besar karsinoma payudara invasif adalah tipe tidak spesifik. ${ }^{14}$ Di Indonesia, lebih dari 70\% kasus ditemukan berada pada stadium yang lanjut, dimana upaya pengobatan sulit dilakukan. ${ }^{15}$ Studi yang dilakukan oleh Sumadi IWJ dan Susraini AAAN di RSUP Sanglah Denpasar menunjukkan bahwa sebagian besar $(66,67 \%)$ pasien karsinoma duktal invasif tipe tidak spesifik hadir dengan metastasis kelenjar getah bening regional dan 58,82\% merupakan derajat tinggi (grade 3) dengan ukuran tumor yang besar. ${ }^{16}$

Perkembangan metastasis limfatik diduga melibatkan proliferasi pembuluh limfatik (limfangiogenesis), invasi limfatik, dan metastasis kelenjar getah bening secara bertahap. Namun, kemungkinan hubungan Lymph Vessel Density (LVD), invasi limfatik (Lymph Vessel Invasion atau LVI), dan metastasis kelenjar getah bening masih belum jelas.3.4 Mekanisme yang menyebabkan sel tumor menyebar melalui pembuluh limfatik (LVI) belum dapat dibuktikan dengan jelas. ${ }^{4}$ Penyebaran preferensial melalui pembuluh limfatik berasal dari frekuensi LVI yang tinggi pada kanker payudara dibandingkan BVI. ${ }^{3}$ Protein kunci yang menginduksi limfangiogenesis adalah reseptor Vascular Endothelial Growth Factor-3 (VEGFR-3), yang diaktivasi oleh Vascular Endothelial Growth Factor-C dan D (VEGF-C dan VEGF-D). ${ }^{3-5}$ Faktor-faktor limfangiogenik ini biasanya diekspresikan dalam selsel ganas, tumor-infiltrating cell dan sel stroma, menciptakan lingkungan yang menguntungkan untuk pembentukan pembuluh limfatik baru. Pembuluh limfatikjuga mengalami perubahan berupa peningkatan jumlah (limfangiogenesis) dan diameter pembuluh limfatik.
Akibatnya, aliran getah bening meningkat sehingga meningkatkan aliran metastasis sel tumor menuju ke kelenjar getah bening dan dapat berkontribusi pada penyebaran sistemik. ${ }^{3,4}$ Namun, sel-sel tumor juga dapat menggunakan penarik fisiologis SDF-1 (juga dikenal sebagai CXCL12) dan CCL21 untuk bermigrasi melalui saluran limfatik menuju kelenjar getah bening regional. ${ }^{3} \mathrm{Hal}$ ini mungkin memberikan harapan target potensial untuk mencegah limfangiogenesis dan metastasis limfatik pada kanker payudara.

Limfangogenesis dapat ditentukan secara kuantitatif yaitu menghitung kepadatan pembuluh limfatik (LVD) dengan menggunakan penanda sel endotel limfatik yang spesifik seperti LYVE-1, Prox1 dan podoplanin/D2-40. ${ }^{3}$ Belum adanya konsensus yang ditetapkan untuk menghitung limfangiogenesis, membuat kuantifikasi LVD lebih menantang daripada kepadatan pembuluh darah/ Blood Vessel Density (BVD).

Metastasis limfatik mungkin tidak secara eksklusif bergantung pada pembentukan pembuluh limfatik baru, meskipun peningkatan LVD secara signifikan meningkatkan potensi sel tumor untuk menginvasi permukaan pembuluh limfatik. Ada kemungkinan bahwa dalam beberapa kasus tumor payudara gagal menginduksi limfangiogenesis dan metastasis limfatik hanya terjadi melalui pembuluh limfatik yang sudah ada sebelumnya. Pembuluh limfatik baru dapat menyediakan jalur tambahan untuk transit sel tumor, sehingga memperkuat aktivitas pro-metastasis dari pembuluh limfatik yang sudah ada sebelumnya yang terletak di perbatasan tumor. ${ }^{3}$ Dibandingkan dengan pembuluh darah, jalur pembuluh limfatik menawarkan banyak keuntungan untuk invasi dan transportasi sel-sel prametastasis, seperti: basal membran yang diskontinyu dan hubungan antar sel yang longgar, laju aliran jauh lebih rendah yang meningkatkan kelangsungan hidup dengan meminimalkan tegangan dan konsentrasi asam hialuronat yang tinggi, bersifat pro-survival terhadap sel tumor., ${ }^{3,17}$ Beberapa penelitian menunjukkan hasil bahwa limfangiogenesis berhubungan dengan LVI dan metastasis kelenjar getah bening. ${ }^{4,8,9}$ Hasil penelitian tersebut konsisten dengan penelitian ini, yaitu terdapat hubungan antara LVD dengan LVI dan metastasis KGB regional. Namun, penelitian yang dilakukan oleh Guleria P et al., menunjukkan bahwa tidak terdapat hubungan antara LVD dengan invasi limfatik dan metastasis KGB. ${ }^{18}$ Hal ini mungkin dapat disebabkan oleh distribusi pembuluh limfatik yang heterogen dan mungkin peningkatan LVD yang ringan dapat terlewat di bagian tumor yang dikhususkan untuk analisis imunohistokimia, meskipun mungkin cukup untuk penyebaran tumor pada pasien. ${ }^{3}$ Hal lain yang juga dapat memberikan hasil yang berbeda adalah metode yang digunakan untuk menghitung LVD termasuk penentuan nilai cut-off LVD, perbesaran mikroskop yang digunakan, jumlah hotspot yang dievaluasi serta analisis statistik yang digunakan juga berbeda.

Status kelenjar getah bening digunakan untuk mengidentifikasi prognosis pasien, stadium tumor dan modalitas terapi. ${ }^{1,6}$ Pasien dengan metastasis kelenjar getah bening regional memiliki resiko enam kali lebih tinggi untuk bermetastasis jauh dibandingkan dengan tanpa metastasis kelenjar getah bening regional. ${ }^{19}$ Metastasis kelenjar getah bening dianggap sebagai faktor prognostik yang paling penting pada kanker payudara. ${ }^{7}$ Sebagian besar karsinoma payudara pertama kali bermetastasis ke kelenjar getah bening regional melalui aliran limfatik., ${ }^{1,2}$ Hal ini sesuai dengan studi yang dilakukan oleh Ran S et al., dalam studi tambahan yang secara kolektif melibatkan lebih dari 3.000 pasien yang menunjukkan bahwa frekuensi invasi limfatik 2-3 kali lebih tinggi dibandingkan dengan invasi pembuluh darah. ${ }^{3}$ Dibandingkan dengan pembuluh darah, jalur pembuluh limfatik menawarkan banyak keuntungan untuk invasi dan transportasi sel-sel prametastasis.

Pembuluh limfatik dianggap memainkan peran pasif dalam metastasis tumor, karena tidak adanya penanda molekuler yang dapat diandalkan untuk membedakan pembuluh limfatik dengan pembuluh darah, serta kurangnya faktor pertumbuhan yang teridentifikasi untuk sistem limfatik. Namun, kemajuan substansial dalam bidang ini dengan cepat mengarah pada pengakuan bahwa sistem 
limfatik berperan aktif dalam banyak tumor ganas. ${ }^{5}$ Pembuluh limfatik dianggap sebagai jalur utama penyebaran sel tumor ke kelenjar getah bening regional dan juga memberi beberapa kontribusi untuk metastasis tumor, seperti penyediaan niche untuk sel induk kanker dan modulasi respon imun antitumor., ${ }^{2,420}$

Invasi limfovaskular (emboli tumor dalam pembuluh darah atau pembuluh limfatik peritumoral) harus dilaporkan ketika ada, karena dikaitkan dengan risiko kekambuhan lokal dan kekambuhan jauh, terutama untuk pasien dengan nodus negatif. ${ }^{4,21}$ Invasi vaskular yang meliputi kedua jenis pembuluh telah lama diakui sebagai indikator prognostik yang buruk. Invasi limfatik memiliki hubungan terhadap peningkatan insiden metastasis kelenjar getah bening regional pada karsinoma payudara invasive., ${ }^{4,21}$ Sebagian besar (75,71\%) karsinoma payudara invasif tipe tidak spesifik hadir dengan invasi limfovaskular yang dievaluasi dengan pulasan $\mathrm{H}$ dan E. ${ }^{22}$ Pembuluh limfatik sulit tervisualisasi pada pulasan rutin $\mathrm{H}$ dan $\mathrm{E}$ dan umumnya tidak mengandung sel darah merah serta dapat berdekatan dengan pembuluh darah kecil. Identifikasi emboli tumor di dalam saluran limfatik lebih dapat diandalkan di area peritumoral. ${ }^{11,23,24}$ Emboli tumor dapat sepenuhnya mengisi lumen limfatik dan tidak dapat dibedakan darisarang sel tumor yaitu artefak retraksi tumor dan agregat tumor yang terisolasi akibat penyusutan jaringan selama fiksasi pada pewarnaan rutin $\mathrm{H}$ dan $\mathrm{E}$. Antibodi monoklonal D240 berguna dan dapat diandalkan untuk mendeteksi invasi limfatik hingga 2 kali lipat bila dibandingkan dengan pulasan $\mathrm{H}$ dan E saja. ${ }^{4,10-12}$ Antibodi monoklonal D2-40 merupakan penanda sel endotel limfatik dengan sensitifitas dan spesifitas tinggi yang terpulas kuat pada sel endotel limfatik tetapi tidak pada sel endotel pembuluh darah. ${ }^{11}$

\section{SIMPULAN}

Terdapat hubungan antara LVD dengan invasi limfatik dan metastasis KGB regional pada karsinoma payudara invasif tipe tidak spesifik. Lymph vessel density yang tinggi memberikan risiko 3,6 kali lebih besar untuk mengalami invasi limfatik dan 1,7 kali lebih besar untuk mengalami metastasis KGB regional dibandingkan dengan LVD yang rendah pada karsinoma payudara invasif tipe tidak spesifik.

\section{KONFLIK KEPENTINGAN}

Penulis menyatakan tidak terdapat konflik kepentingan terkait publikasi dari penelitian ini.

\section{ETIKA PENELITIAN}

Penelitian ini telah mendapatkan persetujuan dari Komite Etik Fakultas Kedokteran Universitas Udayana/RSUP Sanglah Denpasar dengan No. 2306/ UN14.2.2.VII.14/LT/2020.

\section{PENDANAAN}

Penelitian ini tidak mendapatkan bantuan dana hibah dari pemerintah maupun sektor swasta lainnya.

\section{KONTRIBUSI PENULIS}

Seluruh penulis memiliki kontribusi yang sama dalam penulisan artikel penelitian ini baik dari tahap pengumpulan data, analisis data penelitian, hingga laporan hasil penelitian.

\section{DAFTAR PUSTAKA}

1. Wiranata S, Anjani IAW, Saputra IPGS, Sadvika IGAS, Prabawa IPY, Supadmanaba IG, et al. Pretreatment Neutrophil-to-Lymphocyte Ratio and Platelet-to- Lymphocyte Ratio as a Stage Determination in Breast Cancer. Open Access Macedonian Journal of Medical Sciences. 2020;8(B):1058-1063.

2. Paduch R. The role of lymphangiogenesis and angiogenesis in tumor metastasis. Cell Oncol (Dordr). 2016;39(5):397-410.

3. Ran S, Volk L, Hall K, Flister MJ. Lymphangiogenesis and lymphatic metastasis in breast cancer. Pathophysiology. 2010;17(4):229251.

4. Zhang S, Zhang D, Yi S, Gong M, Lu C, Cai Y, et al. The relationship of lymphatic vessel density, lymphovascular invasion, and lymph node metastasis in breast cancer: a systematic review and meta-analysis. Oncotarget. 2017;8(2):28632873.

5. Tammela T, Alitalo K. Lymphangiogenesis: Molecular mechanisms and future promise. Cell. 2010;140(4):460-476.

6. Andree C, Schmidt VJ, Munder BI, Seidenstücker K, Behrendt P, Witzel C, et al. Detecting of breast cancer metastasis by means of regional lymph node sampling during autologous breast reconstruction--a screening of 519 consecutive patients. Med Sci Monit. 2018;18(10):CR605-10.
7. Hermansyah, D, Albar ZA, Purwanto DJ, Sari L, Putri RL. CD 105 as prognostic factors in advanced stage breast cancer patients. Bali Medical Journal. 2017;6(1):227-235.

8. Widodo I, Ferronika P, Harijadi A, Triningsih FE, Utoro T, Soeripto. Clinicopathological significance of lymphangiogenesis and tumor lymphovascular invasion in indonesian breast cancers. Asian Pac J Cancer Prev. 2013;14(2):997-1001.

9. Kandemir NO, Barut F, Bektas S, Ozdamar SO. Can lymphatic vascular density be used in determining metastatic spreading potential of tumor in invasive ductal carcinomas?. Pathol Oncol Res. 2012;18(2):253-262.

10. Kanngurn S, Thongsuksai P, Chewatanakornkul S. Chalkley microvessel but not lymphatic vessel density correlates with axillary lymph node metastasis in primary breast cancers. Asian Pac J Cancer Prev. 2013;14(1):583-587.

11. Kumar A, Pandey V, Ansari MA, Srivastava V, Kumar M. Lymphangiogenesis as a Prognostic Marker in Breast Cancer Using D2-40 as Lymphatic Endothelial Marker-A Preliminary Study. European Journal of Cancer. 2012;45(5):S89.

12. Mohammed RA, Martin SG, Mahmmod AM, Macmillan RD, Green AR, Paish EC, et al. Objective assessment of lymphatic and blood vascular invasion in lymph node-negative breast carcinoma: findings from a large case series with long-term follow-up. J Pathol. 2011;223(3):358-65

13. Tao Z, Shi A, Lu C, Song T, Zhang Z, Zhao J. Breast Cancer: Epidemiology and Etiology. Cell Biochem Biophys. 2015;72(2):333-338.

14. Fulga V, Rudico L, Balica AR, Cimpean AM, Saptefrati L, Raica M. Invasive ductal carcinoma of no special type and its corresponding lymph node metastasis: do they have the same immunophenotypic profile?. Pol J Pathol. 2015;66(1):30-37.

15. Momenimovahed Z, Salehiniya $H$. Epidemiological characteristics of and risk factors for breast cancer in the world. Breast Cancer (Dove Med Press). 2019;11:151-164.

16. Sumadi IWJ, Susraini AAAN. Tingkat Kesesuaian Diagnosis Invasi Limfatik pada Karsinoma Duktal Invasif Payudara pada Pulasan Hematoksilin-Eosin Dibandingkan dengan Pulasan Imunohistokimia VEGFR-3. Majalah Patologi Indonesia Indonesia. 2012;21(1):14-19.

17. Rahman M, Mohammed S. Breast cancer metastasis and the lymphatic system. Oncol Lett. 2015;10(3):1233-1239.

18. Guleria P, Srinivas V, Basannar D, Dutta V. Comparison of lymphangiogenesis, lymphatic invasion, and axillary lymph node metastasis in breast carcinoma. Indian J Pathol Microbiol. 2018;61(2):176-180.

19. Tseng HS, Chen LS, Kuo SJ, Chen ST, Wang YF, Chen DR. Tumor characteristics of breast cancer in predicting axillary lymph node metastasis. Med Sci Monit. 2014;20:1155-1161.

20. Karaman S, Detmar M. Mechanisms of lymphatic metastasis. J Clin Invest. 2014;124(3):922-928. 
21. Widiana IK, Suryawisesa IB, Tirthayasa INW. The role of lymphatic and vascular invasion in lymph node metastasis in T1/T2N0 breast cancer patients at Sanglah General Hospital. Indian Journal of Scientific Research. 2016;7(1):45-53.

22. Sriwidyani NP, Manuaba IBTW, Alit-Artha IG, Mantik-Astawa IN. Tumor budding in breast carcinoma: relation to E-Cadherin, MMP-9 expression, and metastasis risk. Bali Medical Journal 2016;5(3):497-501.

23. Kos M, Lenicek T. Lymphatic and Small Blood Vessel Density in The Tumor and Peritumoral Tissue in Invasive Breast Carcinoma of No Special Type. Croation Journal of Oncology, 2018;46(1):5-13.

24. Zhao YC, Ni XJ, Li Y, Dai M, Yuan ZX, Zhu YY, et al. Peritumoral lymphangiogenesis induced by vascular endothelial growth factor $\mathrm{C}$ and $\mathrm{D}$ promotes lymph node metastasis in breast cancer patients. World J Surg Oncol. 2012;10:165.

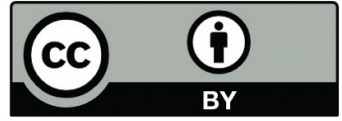

This work is licensed under a Creative Commons Attribution 